\title{
Cash Transfers Matter! A Critique of the Senate Report on Postsecondary Education
}

\author{
JAMES M. DEAN*
}

\begin{abstract}
The Standing Senate Committee on National Finance has recently recommended a major change in the way that the federal government provides support to the provinces for postsecondary education. It recommends that the cash transfers under EPF be eliminated and replaced with additional transfers of tax points to the provinces designed to provide the same amount of money. The Committee believes that the current arrangements do not influence the spending priorities of the provinces and such a change would not alter this fact.

This paper argues that the Senate Report is based on an economic approach to grants that has been under serious question for 15 years. Both the traditional and the modern theory of grants are discussed. It is argued that there are reasons to believe that a change to the new arrangements would influence provincial spending priorities. Empirical estimates of the change show that provincial governments could be expected to decrease their support for postsecondary education by between $\$ 38$ to $\$ 48$ million per year over the next 5 years as a direct result of the proposed change in the way the transfers are made.
\end{abstract}

\section{RÉSUMÉ}

Le Comité sénatorial permanent des finances nationales a récemment recommandé un important changement dans la façon dont le gouvernement fédéral offre son soutien aux provinces pour l'enseignement supérieur. Il recommande que l'on supprime les transferts de fonds effectués en vertudu financement des programmes établis (F.P.E.) et qu'on les remplace par l'octroi aux provinces de points d' impôts additionnels qui leur fourniraient le même montant d'argent. Le Comité estime que les dispositions actuelles n'ont pas d'effet sur le choix des dépenses ayant priorité pour les provinces, et que la modification proposée n'y changerait rien.

*Associate Professor, Department of Economics, St. John's College, University of Manitoba. Financial assistance from the University of Manitoba/SSHRC Fund Committee is gratefully acknowledged. Helpful comments were received from R. Clifton and A. Jefferson. 
Dans cet article, on montre que le rapport du Sénat repose sur une approche économique qui, en ce qui concerne l'octroi des subventions, est sérieusement remise en question depuis quinze ans. On y discute à la fois de la théorie moderne et de la traditionnelle. On y soutient aussi qu'il existe des raisons de croire qu'un changement de dispositions aurait un effet sur le choix des dépenses auxquelles les provinces accordent la priorité. Des estimations empiriques montrent qu'on peut s'attendre à ce que les gouvernements provinciaux réduisent leur soutien à l'enseignement supérieur de 38 à 48 millions de dollars par année durant les cinq prochaines années, et ce, en conséquence directe du changement proposé pour le transfert des fonds.

\subsection{Introduction}

Financial transfers between the federal and the provincial governments have been described as the glue that holds the country together, and the transfers under the general rubric of Established Program Financing (EPF) are an important part of that glue. The EPF transfers are transfers from the federal government to the provincial governments which cover not only postsecondary education but health care and hospitalization as well. Cash transfers under this program in 1986-87 amount to $\$ 9,045$ million, and if the value of the tax points transferred to the provinces are also included, the program cost rises to $\$ 16,729$ million. ${ }^{1}$ Current projections are that the total value of these transfers, including both the cash and the value of the tax point transfers, will rise to $\$ 20,685$ million by $1990-91$. Such large transfers are likely to receive ongoing scrutiny, and indeed this is exactly what has happened. The program has been modified and revamped several times in the past 15 years. There have been caps on the growth of transfers for higher education in 1972 , and again for higher education in the " 6 \& 5" program period in 1883-85. There was also a major change in 1977 which can be loosely interpreted to be a change from a system whereby the federal government cost-shared expenditures in these areas with the provinces to a system which gave unconditional grants to the provinces, a change that is widely predicted to have led the provinces to modify their spending priorities so that less is spent in these areas than would otherwise have been the case.

The Established Program Financing (EPF) has been examined once again and the results of these deliberations are contained in a Senate Report entitled Federal Policy on Postsecondary Education released in March, 1987. The Senate Report has hit upon one of the central features of the program which has been discussed since the changes in 1977, namely the unconditional cash transfers and their relationship with the tax points which were transferred to the provinces at that time. Essentially, the Senate Report holds that there is no analytical distinction between the two ways of transferring money to the provinces since both increase 
provincial revenues with no constraint on how the provinces choose to spend the money. The reasoning is clearly explained in the Report:

Because the money is transferred without safeguards or conditions, it has simply increased provincial government revenues. This does not mean that postsecondary education in Canada has not benefitted from the transferred money; it means, however, that there is nothing to rcconnincid this way - the EPF way - of transferring the money. The only thing which the federal government has done through the transfer of the postsecondary portion of EPF is to contribute to the general revenues of the provincial governments. The same amount of money transferred to each province outside the EPF framework and devoid of conditions might have had the same results. (Senate Report, p. 101)

In making the statement that there is an equivalence between the impact on spending of cash and tax-point transfers, the Senate Report voices the wisdom of the traditional economics approach to this issue. ${ }^{2}$ However, this view of cash transfers has been under serious question for 15 years precisely because it failed to explain adequately the empirical findings on how recipients of transfers actually behaved. Since the Senate Report uses this inadequate approach as the basis for recommending a major change in the way that the federal support for postsecondary education is made available to the provincial governments, it seems that it is time for the challenge to the conventional wisdom to be made more widely available. The recommendation of the Senate Report that is relevant to this discussion is as follows:

The Committee suggests that the solution is for the federal government to terminate the PSE (postsecondary education) portion of EPF (Established Program Financing) and transfer adequate financial resources to the provincial governments. This could be done by converting some or all of the money currently transferred in the form of cash payments into equalized tax points to be given to the provinces along with the personal and corporate tax points already transferred for health and education. (Senate Report, p. 102. Explanation of acronyms added.)

The purpose of this paper is twofold. First, it will explain the reasoning on which the traditional approach to the equivalence of cash transfers and tax point transfers is based and the alternative approaches that are currently emerging. The predictions of the competing theories are different, and the appropriateness of the Senate recommendation is contingent upon which of the approaches is most relevant. However, this discussion might be just an interesting footnote to the Senate Report if the distinction made little difference to the funds that will be available for postsecondary education. Consequently, the paper also attempts to estimate the empirical magnitude of the change in funds available if the recommendation were to be implemented. It will be shown that the funding implications of the Senate Committee recommendation on this issue are potentially very serious for postsecondary education, a possibility not even considered in the Senate Report. 


\subsection{The Traditional Position}

The traditional theory of grants differentiates between grants which alter the price at the margin of decision for the service covered by the grant program, and grants which increase the resources available to be spent on this or other services but do not alter the price of the service at the margin of decision. There are variations on this theme for cases where there are other institutional restrictions such as a restriction that the spending on the relevant program cannot be less than the amount of the grant, but the basic theme differentiates between the effect which arises solely because of an effective increase in the resources available to the recipient unit (the income effect) and an effective change in the price of the service to the recipient (the substitution effect) even if there had been no improvement in the real resource availability to the recipient.

This distinction is very important in understanding the predicted effect of changes in the EPF arrangements. Until 1972, federal assistance for postsecondary education was structured so that the federal government paid 50 percent of the operating costs for postsecondary education. ${ }^{3}$ This effectively reduced the cost of spending in this area for the provinces to 50 cents on the dollar, and it is predicted that they would choose to spend more on this area than would have been the case if they were required to finance the full amount of any additional spending entirely from their own resources. As a result of the 1977 revision of the EPF arrangements, the provinces were able to receive the full amount of the federal grant regardless of what they did with spending on postsecondary education, so that additional spending on higher education effectively cost them $\$ 1$ for each additional $\$ 1$ that they chose to spend in this area. That was because there was no longer any influence on the federal transfers to a province as a result of a province changing its spending on postsecondary education. Since the cost to a province at the margin of decision had risen from 50 cents to $\$ 1$ for each additional dollar that a province chose to spend, it is predicted that each affected province would choose to spend less than otherwise in this area.

The actual situation was complicated by the fact that the federal government had imposed an effective ceiling on federal contributions to spending on postsecondary education in 1972. At that time a ceiling was set so that the federal contribution did not rise by more than 15 percent per year in total for all provinces, a change that Wu (1986) has claimed increased the cost to the provinces at the margin of decision to near $\$ 1$ by 1973 or 1974 . This observation does not detract from the claim that the provinces would choose to spend less on postsecondary education than would have been the case under cost-sharing, but it does suggest that the provinces would have begun adjusting to the removal of cost-sharing in 1973 or 1974 rather than 1977 as is commonly assumed. ${ }^{4}$

However, the changes incorporated in the 1977 arrangements are the ones most relevant to the analysis leading to the recommendation of the Senate Report. At that time the federal government agreed to provide the money for postsecondary education to the provinces in the form of an unconditional transfer. ${ }^{5}$ This ensured 
that the provinces were not obligated to match the federal contribution to postsecondary education and so could allocate their total provincial resources in line with provincial priorities rather than the federal priorities that are evidenced by the amount of the transfers. The federal position was that this program was now "established" so that the stimulus of cost-sharing was no longer necessary. A further feature of the arrangements enabled the federal government to limit the increase in the federal cash contribution to the increase in the real growth in the economy to which, among other things, federal tax revenues were linked. Once it was agreed that the federal transfers would be in the form of unconditional transfers to the provincial governments, the issue reduced to the way in which the unconditional transfers were to be made.

The actual arrangements, with transitional arrangements for levelling up and levelling down are quite complicated, but the basic principle is clear. The money could be transferred in two ways. It could be transferred directly in the form of cash. It could also be transferred in the form of tax points. The transfer of tax points involved the federal government in computing how much its own tax rates on personal and corporate income could be reduced in order to reduce federal tax revenues by the agreed upon amount. Provinces could then raise their own tax rates by an amount that would recover the same agreed amount of tax revenue. ${ }^{6}$ Provincial taxpayers would then pay the same amount of tax but they would pay less to the federal government and more to their respective provincial governments. The 1977 arrangements dictate that the transfers are to be made to the provinces half in the form of unconditional cash transfers and half in the form of a transfer of tax points. It is this division between cash and tax points that is at the heart of the discussion in the Senate Report on this issue.

The traditional theory claims that an unconditional transfer will have the same effect regardless of whether it is made in the form of tax points or cash, provided the amount of money transferred is the same in both cases. This is because there is no change in the effective price of provincial spending in this area at the crucial margin of decision under either choice as compared to a situation where there was no program transfer at all. That is, in both cases the provinces would pay $\$ 1$ from their own resources for each additional $\$ 1$ that they chose to spend on postsecondary education and with the same amount of money involved in the transfer the provinces would make the same decisions on spending in this area (Bradford and Oates, 1971).

In the circumstance, it might seem irrelevant in what form the transfer took place, and, to the extent that the same amount of money is involved, the traditional approach claims that it is irrelevant. However, the tax points were not entirely equalized so that in practice the tax points will generate more revenue for the provinces which have the richest tax bases than for provinces with poor tax bases. The Canadian solution is a compromise, and in this case it amounted to providing half cash and half tax points while guaranteeing that no province would receive less than it would have received if the transfer had all been in the form of cash. Eventually, the tax bases for all of the provinces are expected to grow enough that 
the tax revenue from the new provincial tax points will be as great as the provincial governments would have received from additional cash transfers. However, because of an unexpectedly sluggish growth in government revenues in the 5 years following this arrangement, the 1982 arrangements were modified to ensure the provinces receive as much as they would have received under a cash transfer, but the complicated nature of the institutional arrangements can mask their analytical simplicity. The EPF transfers for postsecondary education became unconditional transfers with the federal government making no unique attempt to ensure that the provinces matched their spending in this area. In practice there were some federal grumblings when it began to emerge that the provinces may have acted upon their incentive to reduce their support for postsecondary education below what would have occurred if the transfers had not been unconditional, but the provincial response was entirely consistent with the analytical principle embodied in the arrangements and should not have been a surprise to any of the parties.

A pattern that emerges is that the federal government has been reducing its stimulus to provincial support for postsecondary education since 1972. The Senate Report is consistent with this pattern. It notes that the effect of both the tax point and the cash transfers is to increase provincial revenues with no restriction on how those revenues are used. A movement toward abolishing the cash transfers in favour of additional tax point transfers can then be seen not as a device to save the federal government money, but as a way of eliminating the federal government presence from an area where the Senate committee thinks there is no clearly defined rationale for the federal government to be involved in the first place. As the Report states:

In the Committee's view EPF is a program which never was intended to have a direct impact on the postsecondary education system in Canada. The same amount of money transferred to each province outside the EPF framework and unrelated to any program could have had exactly the same influence on postsecondary education as the money now transferred under EPF. (Senate Report, p. 95)

The matter of whether the federal government should be involved in the general support of the postsecondary education system is interesting in its own right, but the focus of this paper is to dispute the claim that the elimination of the cash transfers in favour of additional transfers of tax points will not influence provincial behavior.

\subsection{A Critique of the Traditional Approach}

The traditional theory of grants outlined above is a positive theory in that it is designed to give predictions about what will happen to the level of spending on higher education in response to changes in the level of grants. There is nothing implicit in this theory that requires this to be the "correct" level of spending, in any normative sense, and in this respect the modern theory of grants is no different than the traditional approach. However, in the context of the debate over how to finance 
higher education, the positive perspective is an important perspective to maintain. The problem here is to be able to predict what the effect on spending for higher education will be if the grant arrangements are changed, an important piece of information without which informed choices are difficult to make.

The modern theory of grants differs from the traditional theory in that it suggests that the movement from cash transfers to transfers of additional tax points would influence provincial spending in the area of higher education, even if there was no change in the net revenue received by the provinces and even if the cash transfer had been unconditional in the first place. The modern theory has been developed in response to the recognition that the traditional theory does not adequately explain the empirical results from studies of grants. Although the traditional theory predicts that the effect on spending would be the same if the recipient jurisdiction received an increase in its own income or received an unconditional grant of the same amount ${ }^{7}$, the empirical literature suggests that spending is significantly higher when the resource increase is in the form of an unconditional transfer. Mieszkowski and Oakland (1979) note that the literature suggests that "a dollar of unmatched aid results in a 45 cent increase in public spending, while the marginal propensity to spend on local public goods out of income is estimated to be about .10" (Mieszkowski and Oakland, 1979: 1). The Canadian evidence is sparce but supportive. Hardy (1976) explicitly tested both unconditional transfers and provincial income as explanatory variables for spending on postsecondary education in Ontario. He notes: "When, however, Y [per capita net provincial product] and G [per capita Federal unconditional grants] were entered as separate independent variables, the estimated coefficient attached to the unconditional grant variable in the Ontario estimate was both positive and significant. This would appear to indicate that federal grants for postsecondary education were significantly influencing Ontario's educational expenditure decisions" (Hardy, 1976: 184).

The modern approach to the theory of grants assumes that individuals, usually in their role as voters and taxpayers, attempt to maximize their own welfare subject to the constraints they face. The modern theory links voter preferences with the economic outcomes through a political model and so can be viewed as a model of demand for higher education. This approach is individualistic and differs from the approach often found in the traditional literature where the provincial government is viewed as if it was an individual decision unit (Hardy, 1976; Auld, 1976). The difference is significant, since it raises issues that relate to how the decisive voters determine how much spending they desire. There is not one quantity which would be desired by a specific province, but a variety of possible outcomes with the actual outcome dependent on the preferences of the decisive voter. The approach in the public choice literature is to incorporate a median voter model where the decisive voter is assumed to be the voter with the median level of income (Inman, 1978). The relevant preferences are the preferences of the median voter so that changes in the income or price to the median voter lead to a prediction that the desired level of spending will change. ${ }^{8}$ 
There are a variety of possible ways in which the constraints faced by the median voter could change and it is useful to consider each one. Different writers have concentrated on different factors so that it appears that there are several explanations of why the median voter would prefer a change in the level of spending. However, all of the contributions propose to improve on the traditional model by offering a better explanation of what actually happens. One survey of these theories is to be found in Fisher (1982). The alternative approach has been dubbed a "flypaper" theory of grants since it purports to address why it is that money sticks where it is thrown (Courant, Gramlich and Rubinfeld, 1979: 6).

The first possibility is that the model needs to be refined to more accurately represent the situation for the median (decisive) voter. It may be that the resources available to the median voter are different if there is a cash transfer from the federal government as opposed to a substitution of provincial for federal taxes when a tax point transfer is made. This is because the increase in the median voter's tax payments to the province need not equal its share of the cost of the cash transfer. For example, some jurisdictions have the ability to export some of their tax burden onto non-residents, and so the tax increase on the residents to raise the revenue to replace the cash transfers is accordingly lower. Also, the type of tax structures, both in terms of bases and progressivity, are different for the federal and provincial governments. This means that the relative position of the median voter is likely to be different and so the relative cost of financing transfers for postsecondary education will be different also. These arguments suggest that the taxes of the median voter may well change even if the overall resources available to the province are unaffected. The "flypaper" theories would then predict that the median voter would desire a different level of spending whereas the traditional theories would predict that the desired level of spending would be unaffected.

The second possibility is that there is some misperception by provincial taxpayers about the true cost of postsecondary education when the federal government transfers cash to the provinces. This amounts to there being some fiscal illusion for taxpayers, a possibility that is ignored in the traditional theory. Both Courant, Gramlich and Rubinfeld (1979) and Oates (1979) suggest that the decisive provincial taxpayer acts as if the total cost of higher education is really lower by the amount of the grant so that the price per unit is lower for the quantity received. This amounts to the taxpayer reacting to what is perceived to be the average price of postsecondary education rather than the real marginal price that traditional economic models concentrate upon. Under this scenario the decisive taxpayer wants more of what is perceived to be a cheaper service than would have been desired if the provinces had not received the cash transfer. If the cash transfer was eliminated in favour of the transfer of tax points to the provinces, the decisive provincial taxpayer would recognize that their own provincial taxes were rising in order to finance increased spending on postsecondary education. There would be a more direct link between the provincial taxes and provincial spending. In this case the decisive voter would desire less spending on postsecondary education 
precisely because the true resource cost of such services was more clearly recognized. A very simple version of such a model is developed by Oates (1979).

In the context of the Senate Report, the fiscal illusion argument suggests that there is likely to be a significant negative impact from the elimination of the cash grants even if the provinces raise the same additional resources from their own taxpayers with no net increase in the total cost to provincial taxpayers. Of course, improving the information on which voters decide should also improve the decisions that taxpayers make, although the presence of other constraints makes it impossible to tell if the movement is in the direction that the taxpayer would desire if all other costs and benefits were accurately included. The important point to emphasize is that the fiscal illusion argument predicts that the Senate Committee recommendation would result in less provincial government support for higher education.

A third possibility is developed by Hamilton (1983). This argument suggests that taxpayers are able to receive the education services that they desire partly from the public sector and partly from the private sector. Furthermore, as their income rises they are able to use the services provided by the public sector more efficiently because they are able to afford more of the complementary services available in the private sector. For example in postsecondary education, students are required to purchase some books and materials, and these materials are complementary to the course instruction provided. Indeed they are substitutes for the provision of such materials in such places as university libraries and entail much lower transaction costs to read and reference. The higher the student income the more such complementary materials they are likely to have. Consequently, an increase in income has the effect of enabling the student to use the system more efficiently and so, other things being equal, less public spending on postsecondary education is required. Second, there is an additional effect since the public sector price for a unit of education services drops as students supply more of the inputs and this will tend to encourage more spending in this area. Essentially students are paying a greater part of the cost of their education. The relative strength of these two effects, induced by a change in income but not by a change in unconditional grants, will determine what happens to the desired level of spending on postsecondary education. In Hamilton's model (1983) it implies that there will be less spending induced by an increase in income than there is for an increase in unconditional grants. In the case of the Senate Committee proposal, the increase in income for provincial taxpayers is induced by the effective decline in federal taxes used to finance the grants. Taxpayers may then decide to restore some of the funding from increases in provincial taxes but they might then also attempt to keep a portion of the tax change in the form of lower provincial taxes or decide to increase spending in other areas. The essential point is to recognize that there is no reason to assume the effect will be neutral.

Another of the "flypaper" theories also focusses on the supply side of the provision of public services rather than restricting the analysis to changes in the 
constraints of the median voter on the demand side. One such model is developed by Romer and Rosenthal (1980). The basic argument here is that government officials attempt to keep resources in the public sector because it is in their best interest to do so. This approach is in the tradition of the theories of bureaucracy that focus on the self-interested behaviour of public employees. Government officials have an incentive to maintain public spending higher than the median voter desires, and to the extent that they are successful, spending becomes less responsive to changes in the income level of the median voter. A change in the income of the median voter does not change the current level of spending, just the unobserved level desired by the median voter. However, a change in the resources available to the government officials does change the level of spending. In Romer and Rosenthal (1980) an increase in an unconditional grant does not change the unobserved level desired by the median voter, but does increase the resources that the public sector could appropriate without making the median voter any worse off and so results in greater public spending than would an equivalent change in income alone. In the case of the Senate Report, there is a reduction rather than an increase in the cash grant component, so the effect would be in reverse. The provincial government would lose access to a large unconditional grant and would be unable to maintain spending without increasing provincial taxes. This increases the provincial taxpayers' resistance to the relatively high level of spending previously in effect and so is predicted to result in less spending on postsecondary education.

This section is meant to show that, contrary to the prediction of the traditional theory of grants, there is reason to think that the substitution of tax points for cash transfers will not have a neutral effect on provincial spending on postsecondary education. The modern theory of grants links the decision on spending, through the political process, to the preferences of the median (decisive) voter and the constraints that apply to the median voter. There are several reasons to think that the change will not be neutral from the perspective of the decisive voter even if the overall resource change to any provincial government could be neutral. More caution is appropriate than is observable in the Senate Report.

\subsection{Is The Impact Significant?}

Some estimate of the likely impact of a change in the federal financing of higher education is appropriate. This is difficult for Canada because of the paucity of empirical work that can be directly used to address the problem. There are a number of studies exploring the impact of grants on spending, but only one which provides consistent and unconstrained estimates of the impact on spending for higher education of both increases in own provincial revenues and unconditional grants. This is a study by $\mathrm{Wu}$ (1986) ${ }^{9}$ Using the pooled estimates for all provinces for a 15 year period (1967-1982) the empirical evidence in Wu (1986) suggests that there is a substantially different effect when a province receives an unconditional cash grant than is the case when the province raises revenue from its own tax 
sources. Wu estimates that a $\$ 1$ increase in own provincial revenues is associated with an increase in spending on postsecondary education of 2.8 cents. The corresponding increase is 70.6 cents for each $\$ 1$ in income received in the form of an unconditional grant from the federal government. The results suggest that substituting more tax room for less cash subsidies would result in a net decrease in spending on higher education of 67.8 cents per dollar of transfer involved. ${ }^{10}$

There are $\$ 2.9$ billion of cash transfers designated nominally for postsecondary education in 1987-88. These estimates might be used to suggest that provincial spending on higher education could fall by $\$ 2.0$ billion, an extreme result that does not recognize the tendency for governments to not actually reduce the nominal level of support to postsecondary education. ${ }^{1}$ The provinces will likely desire to spend less but the provinces are more likely to reduce support for postsecondary education by reducing the rate of increase in their support over time. Even with low rates of inflation such a policy can reduce the real level of support substantially. Using this more conservative interpretation of the political economy of grants implies the increase in spending on postsecondary education will fall as provincial revenues increase more from own tax sources and less from unconditional transfers. $^{12}$

Using the estimates of $\mathrm{Wu}$ (1986) the impact of these changes on spending on postsecondary education is estimated and the results are shown in Table 1. The stimulus to provincial support of postsecondary education, both from the unconditional cash transfers and the tax points, are estimated at between $\$ 44$ and $\$ 57$ million a year over the next 5 years under the current arrangements. If the Senate Committee proposal were implemented, and the existing unconditional cash transfers were replaced with additional transfers of tax points, the stimulus to provincial support for postsecondary education is estimated at between $\$ 8$ and $\$ 9$ million per year over the same period. This would amount to a reduction of between $\$ 38$ and $\$ 48$ million per year of provincial support for postsecondary education. The shift from using a combination of unconditional cash transfers and tax point transfers to a system based on using only tax point transfers is estimated to have a significant impact on spending on higher education. The reason is that an increase in own revenues stimulates a much smaller increase in spending on postsecondary education than does an unconditional transfer generating the same amount of revenue for the provincial government.

Of course, the federal government has not been a passive provider of unconditional transfers to the provincial governments. The federal government has been vocal in its concern over the changed spending priorities of the provincial governments. Indeed, it has consistently pointed out the size of the transfers involved in the tax point transfer of 1977 whereas the provinces might reasonably begin to think that these are their own revenues, raised by provincial taxes and for which they are responsible to provincial voters. In fact, the public pressure by the federal government may have encouraged the provinces to spend more of the revenues from the tax-point transfers on EPF programs than they would have chosen to spend if the taxes were raised from new tax initiatives of their own 


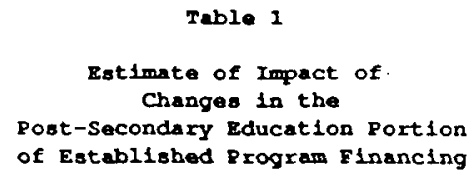

\begin{tabular}{|c|c|c|c|c|c|c|}
\hline \multirow{4}{*}{ Year } & \multicolumn{2}{|c|}{ Value of } & \multicolumn{2}{|c|}{ Increase in } & \multirow{2}{*}{\multicolumn{2}{|c|}{$\begin{array}{l}\text { Increase in Spending } \\
\text { Induced by Iransfers }\end{array}$}} \\
\hline & \multirow[t]{2}{*}{ Cash } & \multirow{2}{*}{$\begin{array}{c}\text { Tax } \\
\text { oint: }\end{array}$} & \multirow{2}{*}{$\begin{array}{c}\text { Cash } \\
\text { Transfers }\end{array}$} & \multirow{2}{*}{$\begin{array}{l}\text { Tax-point } \\
\text { Transfers }\end{array}$} & & \\
\hline & & & & & $\begin{array}{c}\text { Current } \\
\text { Arrangements }\end{array}$ & $\begin{array}{c}\text { Senate } \\
\text { Proposal }\end{array}$ \\
\hline & $s$ & $s$ & $\$$ & $s$ & 5 & $s$ \\
\hline $1986-87$ & 2,903 & 2,467 & & & & \\
\hline $1987-88$ & 2,959 & 2,722 & 56 & 255 & 46.7 & 8.7 \\
\hline $1988-89$ & 3,011 & 2,985 & 52 & 263 & 44.1 & 8.8 \\
\hline $1989-90$ & 3,060 & 3,256 & 49 & 271 & 42.2 & 9.0 \\
\hline $1990-91$ & 3,132 & 3,508 & 72 & 252 & 57.9 & 9.1 \\
\hline
\end{tabular}

Source: Calculated from Eederal Policy on Post-Secondary Education: Report of the standing senate committes on National Finances, Table 2.8, P.26.

Notes: 1. The value of the casb transfers and tax-polnte for post-aecondary education 18 found by assuming that 32.1 percent of the total EpF transfers are allocated to this spending area. This division is essentially arbitrary as recognized by the Senate Report.

2. Cash transfers are assumed to induce 70.6 centa of additional spending on post-secondary education for each $\$ 1$ of additional transfer from the federal government. See the (1986).

3. Tax-pointo transfers are asumed to induce 2.8 cents of additional spending on post-secondary education for ach $\$ 1$ of tax revenue involved in the tranafer of tax room from the federal government. See Wu $(1986)$.

choice. If this is the case then the Wu (1986) estimates for spending on postsecondary education out of own revenues are too low for the tax-point transfers, and the impact of the move away from cash transfers would be smaller than is implied in Table 1.

\subsection{Summary and Conclusions}

The Senate Report has recommended that the federal government eliminate cash transfers under EPF in favour of additional tax-point transfers from the federal government to the provincial governments. This effectively reduces the amount of taxes that people pay to the federal government and increases their tax obligations to the provincial governments by the same amount. It is important to emphasize that the total tax liability to both levels of government does not change, only the distribution of the tax liability between the federal and the provincial governments. 
The position of the Senate Report is that the federal government never intended to have a direct impact on higher education through the EPF arrangements and even if it did, unconditional cash transfers are an ineffective way of influencing the spending priorities of the provinces. Consequently, eliminating the cash transfers from the federal government and having the provinces increase their own tax revenues by the same amount, leaves the provinces with the same amount of money and less federal government presence in an area where the federal government has both no articulated federal objective and no influence on provincial decisions.

This paper addresses one of these issues, the claim that the federal government does not influence the spending priorities of the provincial governments when it makes unconditional cash transfers under EPF. The argument advanced in this paper is that unconditional transfers do influence the spending priorities of the provincial governments and that the modern literature on grants has developed a variety of models to explain the consistent empirical findings that this is the case. There is reason to believe that the position advanced by the Committee is too simplistic in that it does not capture either the complicated nature of the decisions that taxpayers are required to make or the complicated institutional arrangements that might prevent such a neutral effect from occurring.

This is not a disagreement over how to best formulate a theory of grants. At a time when postsecondary education is facing some serious decisions, some of which result from years of provincial financial restraint on the institutions of higher learning, a major change in the EPF arrangements in the way envisaged by the Senate Report could result in an even greater restraint by the provinces than would otherwise have been the case. The Senate Committee might have adopted a position that spending in the area of postsecondary education needs to be reduced, and if that had been the case then the debate would be over the normatively appropriate level of support. However, the arguments developed here are very relevant to the policy debate over the actual recommendations of the Senate Report. The Senate Report is arguing that its proposal would not change the stimulus that the existing grants provide to the provinces with regard to spending in this area. Surely it is folly to procede without being aware of the unintended impact that such a change could be expected to have. Maybe the Senate Committee will have no significant impact on federal government policy, but it would also be folly to assume that this is so and fail to point out the implications of the proposal. This is the kind of proposal that might be particularly attractive to a federal government committed to greater provincial automomy. It deserves to be subjected to careful scrutiny.

\section{NOTES}

1. Federal Policy on Postsecondary Education, p.26

2. The assumption is so deeply ingrained in the economics literature that it is rarely recognized explicitly, but it is embodied in the discussion. See, for example, Courchene (1979) or Boadway 
(1980). Kapsalis (1982) expresses disagreement with the assumption that the 1977 arrangements were a shift from cost-sharing to block funding for health care and hospitalization, but does not question the equivalence of the cash and tax point transfers in his analysis. However, Kapsalis (1982) explicitly references the literature which challenges the traditional view that block funding is neutral.

3 The 50 percent cost sharing applied to seven of the provinces. Three provinces, Newfoundland, Prince Edward Island and New Brunswick received per capita grants and so were effectively block funded already.

4. Kapsalis (1982) notes that the changes introduced in 1972 probably had the effect of moving the system toward block funding before 1977 , but then explicitly uses the 50 percent cost-sharing formula for the pre-1977 period in Table 3, p. 225.

5. The EPF arrangements also covered health care and hospitalization, but the shift to block funding is more questionable for these programs because of the complicated manner in which the cost-sharing was structured prior to 1977. See Kapsalis (1982).

6. A tax point amounted to 1 percent of the Basic Federal Tax attributable to each province. The tax point transfer was subject to equalization so that the yield to each province was brought up to the level of the national average yield. This ensured that poor provinces did not lose as a result of having tax bases poorer than the national average.

7. Slack (1980) is an excellent example of this approach. In this study, the empirical results are restricted to give the same result regardless of the source of the increase in resources. No inconsistency in the theory is noted because none is permitted to exist.

8. If the demand for the public service is single peaked, then voters with less income will demand less of the service and voters with more income will demand more. In practice, there are significant factors other than income to consider and these are included in a median voter model. Inman (1978) has a test of whether the median voter is actually decisive, and finds strong support for the proposition that it is. For a critical examination of the median voter model, from a theoretical perspective, see Romer and Rosenthal (1979).

9. Wu (1986) develops a model of the reduced form:

$\mathrm{E}=(\mathrm{R}, \mathrm{G}, \mathrm{m}, \mathrm{N})$

where $\mathrm{E}=$ per capita gross provincial expenditure on postsecondary education by province in constant 1971-72 dollars.

$\mathrm{R}=$ per capita provincial government revenue by province in constant $1971-72$ dollars .

$\mathrm{G}=$ conditional or unconditional federal grant per capita by province in constant 1971-72 dollars.

$\mathrm{m}=$ net marginal price of higher education, by province

$\mathbf{N}=$ full-time equivalent postsecondary education participation rate, by province (in percent)

The study covers the period 1967-1982. The pooled time series and cross section result from a two-stage least-squares analysis is:

$$
\begin{aligned}
& \mathrm{E}=\mathrm{b}_{0}+\mathrm{b}_{1} \mathrm{R}+\mathrm{b}_{2} \mathrm{G}+\mathrm{b}_{3} \mathrm{~m}+\mathrm{b}_{4} \mathrm{~N} \\
& 16.764+.0286+.7061-.1023-5.3261 \quad \text { Adj. } R^{2}=.63 \\
& \begin{array}{lllll}
(2.84) \quad(6.36) & (4.18) & (-2.27) & (2.05)
\end{array}
\end{aligned}
$$

NOTE: the figures in parentheses are t-ratios.

10. These results are more divergent than the U. S. evidence on the same issue. Caution is appropriate when interpreting the precise coefficients in the model.

11. For example, recall the difficulties when the Province of British Columbia reduced university budgets in nominal terms.

12. Note that Wu uses own provincial income to the provincial government rather than a measure of the income available in the province. This permits a test of the respective strengths of own revenue and unconditional grants that is not possible if net provincial product (Hardy, 1976) or a similar aggregate income variable is used. 
Cash Transfers Matter! A Critique of the Senate Report on

31 Post-Secondary Education

\section{REFERENCES}

Auld, D. A. L., (1976) "Provincial Grants and Local Government Expenditure." 4 Public Finunce Quarterly, pp. 295-305.

Boadway, R. W., (1980) Intergovernmental Transfers in Canada, Financing Canadian Federation no. 2, (Canadian Tax Foundation, Toronto).

Courant, Paul, Edward Gramlich and Daniel Rubinfeld, (1979). "The Stimulative Effects of Intergovernmental Grants: Or Why Money Sticks Where It Lands," in Peter Mieszkowski and William Oakland, eds. Fiscal Federalism and Grants in Aid, (The Urban Institute, Washington) pp. 5-22.

Courchene, T. J., (1979) Refinancing the Canadian Federation: A Survey of the 1977 Fiscal Arrangements Act, (C. D. Howe Research Institute, Montreal).

Fisher, Ronald C., (1982) "Income and Grant Effects on Local Expenditure: The Flypaper Effect and Other Difficulties," $/ 2$ Journal of Urban Economics. pp. 324-345.

Hamilton, Bruce W. (1983) "The Flypaper Effect and Other Anomalies," 22 Journal of Public Economics, pp. 347-361.

Hardy. H. M., (1976) "Budgetary Responses of Individual Governmental Units to Federal Grants," 4 Public Finance Quarterly, pp. 173-186.

Inman, R. P. (1978) "Testing political economy's 'as if' proposition: is the median income voter really decisive?" Public Choice 33: 45-65.

Kapsalis, C., (1982) "Block-Funding and Provincial Spending on Social Programs." 30 Canadian Tax Journal, pp. 219-227.

Mieszkowski, P. and W. Oates. (1979) eds. Fiscal Federalism and Grants in Aid. (The Urban Institute. Washington).

Oates, Wallace, (1979) "Lump-Sum Intergovernmental Grants Have Price Effects." in Peter Mieszkowski and William Oakland, eds. Fiscal Federalism and Grants in Aid. (The Urban Institute, Washington) pp. 5-22.

Romer, T. and H. Rosenthal, (1979) "The Elusive Median Voter." 12 Journal of Public Economics, pp. $143-170$.

Romer, T. and H. Rosenthal, (1980) "An Institutional Theory of the Effect of Intergovernmental Grants," 33 National Tax Journal, pp. 451-458.

Slack, Enid, (1980) "Local Fiscal Response to Intergovernmental Transfers," 62 Review' of Economics and Statistics. pp. 364-370.

Wu, Yuk Shing, (1986) Provincial Budgetary Response to Federal Post-secondary Edacation Transfers in Canada. unpublished Ph.D. dissertation, University of Manitoba. 